\title{
ОБГРУНТУВАННЯ КОМПЛЕКСНОГО ПОКАЗНИКА ВИТРАТ ПІДПРИЄМСТВА НА КОНСАЛТИНГОВІ ПРОЕКТИ
} SUBSTANTIATION OF THE COMPLEX INDICATOR
OF THE COMPANY'S COSTS FOR CONSULTING PROJECTS

\author{
Дзюба Оксана Миколаївна \\ кандидат економічних наук, доцент, \\ Національний транспортний університет \\ ORCID: https://orcid.org/0000-0002-2411-5844 \\ Левіщенко Олена Степанівна \\ аспірант, \\ Національний транспортний університет \\ ORCID: https://orcid.org/0000-0003-3704-5352
Dziuba Oksana, Levishchenko Olena National Transport University

\begin{abstract}
Стаття розглядає актуальне питання формування, обґрунтування і складових розрахунку комплексного показника витрат підприємства-замовника на консалтинговий проект для подальшого розрахунку показника економічності такого проекту як співвідношення досягнутого результату до витрат. Було показано, що для замовників зовнішнього консультування витрати на консалтинговий проект формуються в інший спосіб, ніж для консалтингової компанії. Було обґрунтовано доцільність визначення витрат в окремих випадках не у грошових одиницях, а у формі комплексного показника. На основі аналізу методик оцінювання витрат в наслідок ризиків було розроблено авторський методичний підхід для розрахунку комплексного показника витрат підприємства на консалтинговий проект, який враховує не лише розмір витрат, але й імовірність прийняття і впровадження замовником цього проекту, й експозицію - частоту консалтингової взаємодії.

Ключові слова: витрати, консалтинговий проект, методика risk score, ймовірність, експозиція.
\end{abstract}

В статье рассматриваются актуальные вопросы фрормирования, обоснования и составляющих расчета комплексного показателя затрат предприятия-заказчика на консалтинговый проект с последующим использованием этого показателя для расчета экономичности такого проекта как соотношения полученных результатов к затратам. Было показано, что для заказчиков внешнего консультирования затраты на консалтинговый проект фрормируются иначе, чем в консалтинговых компаниях. Было обосновано полезность определения затрат в некоторых случаях не в денежных единицах, а в форме комплексного показателя. На основании анализа методик оценивания потерь от рисков был разработан авторский подход по расчету комплексного показателя затрат предприятия на консалтинговый проект, в котором учитываются не только размеры затрат, но и вероятность принятия и внедрения заказчиком проекта, и экспозиция - частота консалтингового взаимодействия.

Ключевые слова: затраты, консалтинговый проект, методика risk score, вероятность, экспозиция.

The article considers the actual issue of formation, substantiation and components of calculation of the complex cost indicator of the customer enterprise for a consulting project for further calculation of the traditional performance indicator of such a project as the ratio of the achieved result to costs. The method used for calculations was based on a modified risk score approach as a comprehensive indicator of the product of values of three levels: payment to a consultant, exposure, which takes into account the frequency of consulting interaction and the probability that the consulting project will be accepted and implemented by the customer. The article considers one of the indicators of evaluation of the effectiveness of consulting projects - an indicator of effectiveness, which is traditionally calculated as the ratio of project results to costs. It has been shown that for customers of external consulting, the costs of a consulting project are formed in a different way than for a consulting company. The expediency of determining costswas substantiated in some cases not in monetary units, but in the form of a comprehensive indicator. Based on the analysis of methods for assessing costs as a result of risks, the author's methodological approach was developedto calculate the complex indicator of the company's costs for a consulting project, which takes into account not only the amount of project costs, but also the probability of acceptance and implementation by the customer of this project, 
and the exposition - the frequency of consulting interaction of the client with the consultant. The higher the levels of these three values, the greater the cost score. This is expedient for the customer enterprises of external consulting, because the costs for them are significantly different from the costs of the same project of a consulting firm. Such a comprehensive cost indicator allows to take into account the difference in the payment of consultants' services, the frequency of consulting interaction and the likelihood that the project will be accepted for implementation by the customer in whole or in part.

Keywords: expenses, consulting project, risk score methodology, probability, exposure.

Постановка проблеми. Аналіз ринку консалтингових послуг України показав високий рівень недовіри менеджменту компаній до зовнішнього консалтингу як до есрективного механізму поліпшення діяльності підприємства. Проблемою при залученні зовнішніх консультантів $€$ оцінка замовником ефективності їх послуг. Для цього використовується параметр економычносты як співвідношення отриманого результату до витрат замовника на проект. I якщо результати оцінюються не у грошовому виразі, то витрати також потребують вираження не у грошових одиницях.

Аналіз останніх досліджень і публікацій. Теоретичною та методологічною основою нашого дослідження стали праці вчених та практиків Верби В.А., Євтушенко Н.О., Бортнікової М.Г., Трофрімової О.К., Чайки І.П., Аппельбаума С.Х., Ліппіта Г., Хайта М., що заклали підвалини дослідження консалтингу як всесвітньої галузі економіки та визначення ефрективності цієї діяльності, також роботи Вітлінського В.В., Івченко І.Ю., Г. Гранатурова В.М. по оцінці економічних ризиків. Але частина питань щодо фрормування та методичного забезпечення оцінки витрат на консалтингові проекти в процесі консалтингової взаємодії залишаються відкритими.

Виділення невирішених раніше частин загальної проблеми. При розрахунку ефективності консалтингових проектів як співвідношення результату до витрат підприємства останні не завжди доцільно визначати у грошових одиницях, якщо показник результату $\epsilon$ інтегральним. Тому постає питання, як розраховувати комплексний показник витрат саме для підприємств-замовників.

Формулювання цілей статті (постановка завдання). Мета дослідження - аналітичне обґрунтування можливості використання комплексного показника витрат на консалтинговий проект і розробка авторського методичного підходу до розрахунку такого показника.

Виклад основного матеріалу дослідження. При реалізації консалтингових проектів замовник потребує оцінки їх результативності. Якщо обидва параметри: результатів проекту і витрат на нього виражені у грошових одиницях [1, с. 44], то розрахувати економічний ефект легко. Якщо ж результати проекту оцінюються інтегральними показниками; за даними експертних опитувань тощо, виражати параметр витрат у такій моделі грошовими одиницями недоцільно.

3 іншого боку витрати для розрахунку економічної ефрективності консалтингу, які визначаються таким співвідношенням консалтинговими компаніями - надавачами послуг, це не ті суми, які витрачає компанія - замовник на консалтинговий проект. Так консалтингові срірми включають у розрахунок витрат власні витрати на забезпечення роботи консультантів та розробку консалтингового продукту i, на його основі, консалтингових проектів, що $\epsilon$ основою для виставлення рахунків на оплату замовникам. А ці оплати від замовників для консалтингової фрірми є доходом.

Якщо ми оцінюємо ефеективність консалтингового проекту для підприємства-замовника, то параметр витрат для нього зазнає значних деформацій. В загальному вигляді витрати підприємства в процесі консалтингової взаємодії можна поділити на дві великі групи. Перша - це оплата консалтинговій компанії за ії̈ послуги згідно виставлених рахунків: оплата роботи консультанта, яка у бухгалтерії підприємства обліковується на рахунках 91, 92, 93. Друга група витрат - це витрати підприємства безпосередньо на реалізацію проекту і вони фрормуються з витрат на ті заходи, на які погоджується менеджмент підприємства. Ці складові витрат можна виразити у грошових одиницях, але суми характеризуватимуться великим розкидом. При оцінці витрат на консалтингові проекти в межах бюджетного року платежі можуть бути як авансові, так і лише по фракту впровадження окремих етапів проектів, крім регулярних платежів контракт може передбачати премії консультантам, при розірванні контрактів до завершення запланованого року компанія може виплачувати штрасри. Замовник може не погодитись оплачувати консультанту надані послуги повністю, або частково; 3 іншого боку, навіть оплативши їх, менеджмент підприємства-клієнта може не впроваджувати 
розроблений проект або впроваджувати своїми силами без участі консультанта, або лише частково ті заходи, які видаються дешевшими чи $€$ першочерговими - тобто умови оплати можуть змінюватись на етапах розробки і реалізації консалтингового проекту, як з ініціативи однієї із сторін консалтингової взаємодії, так і через ризики появи непереборних обставин.

Всі ці платежі відрізнятимуться не лише за розміром, але буде велика диференціація їх за призначенням, регулярністю, етапом проектування та й типом проекту, на якому вони 3'являються, механізмом оплати, ймовірністю їх появи. I важко виокремити всі витрати, просумувати їх на один момент часу для розрахунку таким чином параметру витрат для визначення ефективності консалтингового проекту саме для компанії-замовника.

В моделях для витрат на консалтингові проекти вченими пропонується враховувати різноманітність практик оплати консультантам їх роботи. Так, Бортнікова М.Г. пропонує триступеневий механізм оплати послуг консалтингових підприємств [2, с. 133].

Тому при врахуванні досвіду практиків, ринкової інсрормації по Україні, аналізі наукових розробок для підприємств різних галузей, теоретичних роздумів, ми можемо розглянути основні проблеми та положення в сучасній практиці срормування витрат підприємств на зовнішній консалтинг.

Основою цих витрат є виплати консультантам за виконану роботу. Але хоча консалтинг $\epsilon$ окремим видом діяльності, до консалтингових послуг відносять часто і послуги з аудиту, юридичні, по підбору персоналу тощо. Зважаючи на різноманіття ринку консалтингових послуг, рівня консультантів, які надають ці послуги та сум, які готові витрачати компанії на зовнішній консалтинг, сума оплати години роботи консультанта варіюється на ринку України від 20 до 10000 доларів США за годину. Оплата розраховується від кількості витраченого консультантом часу. Недоліком цього підходу $є$ те, що клієнту дуже важко проконтролювати, скільки насправді часу витрачає консультант на розробку консалтингового проекту. Також практики часто вказують на те, що клієнту психологічно важко довгий час (більше місяця) погодинно оплачувати роботу висококваліфікованих консультантів, тому для таких проектів частіше обирають фріксовану оплату [3]. Іноді використовують метод аналогів, посилаючись на реалізовані на ринку консалтингові проекти. Для специфрічних послуг використовують аналоги оплати праці спеціалістів дублюючих чи суміжних галузей (юристів, тренерів, фрасилітаторів, аудиторів тощо). Другою поширеною практикою оплати консалтингових послуг $€$ фрормування суми «від успіху». I найскладніше у цьому випадку визначити наявність успіху консультування та кореляцію зміни показників успішності організації саме від провадження рекомендацій консультантів. Так деякі називають найкращим індикатором зміну ринкової вартості компанії чи приріст річного прибутку підприємства [4], але в умовах України для підприємств будівництва це реалізувати досить важко. Виключенням може бути винагорода за успіх при консалтингових послугах по офрормленню та виграшу тендерів. Частина практиків із великих консалтингових фрірм наголошують на тому, що такі гонорари, що залежать від успіху, неетичні. 3 іншого боку така оплата «за успіх» доцільніша, а обґрунтувати це твердження можна тим, що для консультанта, який надає послуги, інтереси клієнта мають переважати над інтересами його консалтингової компанії. I в цьому випадку оплата консалтингових послуг за витрати часу не в інтересах клієнта, хоч вигідніша консультанту, якого важко проконтролювати, як ми казали вище.

Також оплату консалтингових послуг «від успіху» важко застосовувати, адже вона містить у собі ризик відмови замовника від послуг консультанта, але впровадження проекту власними силами організації. Тобто якщо консультант з різних причин не може приймати безпосередню участь у всіх стадіях розробки і реалізації консалтингового проекту (що є витратним для замовника), то всім учасникам досить важко дійти згоди про його внесок в успіх організації, що часто призводить до провалу консалтингової взаємодії.

Щодо причин відмови від проектів стороною замовника, то причинами їх може бути висока вартість послуг консультантів, розходження пропозицій консалтингового проекту і бачення шляху розвитку компанії їі керівництвом, рішення керівництва щодо того, що послуги консультанта на певному етапі консалтингової взаємодії не потрібні (їх не варто оплачувати), а запропоновані зміни у діяльність підприємство можна впроваджувати повністю чи частково без участі консультанта відповідно до пріоритетів і бачення менеджменту компанії.

Для розрахунку показників результативності, економічності, ефрективності (залежно від потреб осіб, які приймають рішення), де результати виражені інтегральним безроз- 
мірним параметром, витрати також доцільно виразити не у грошових одиницях, а як безрозмірний параметр, який врахує не лише розмір оплати консультанта, але й періодичність і форму здійснення виплат, а також ймовірність відмови підприємства від консалтингового проекту на різних стадіях його впровадження. Це дозволить зберегти фрізичну суть показника економічності як співвідношення результатів проекту до витрат на нього, адже важливі не конкретні суми, а те, чи більші досягнуті результати за витрати на проект. Так, наприклад, в моделі оцінювання ефективності консалтингового процесу Верба B.A. пропонує користуватись системою трьох взаємопов'язаних параметрів - результату, ймовірності його досягнення і вартості ресурсів, необхідних для досягнення результатів при прогнозному рівні ризиків [5].

Для фрормування параметру витрат нашим методом пропонуємо використати підхід по розрахунку показника ризику, який так само дозволяє враховувати не тільки витрати в грошовому виразі (втрати від ризику), але й імовірність їх появи [6, с. 64]. Існує багато методик оцінки ризику, для окремих ризиків при розрахунку результуючої оцінки використовують не лише розмір втрат і їх імовірність, але й частоту таких ризикових подій, наслідками яких можуть бути втрати [7, с. 91-93].

Ми пропонуємо для визначення параметру витрат на консалтинговий проект використовувати модифіковану методику risk score [8], де для визначення результуючого безрозмірного комплексного показника використовують три складові: розмір витрат, експозицію або шкалу частоти і ймовірність цих витрат.

$$
\begin{gathered}
\text { В = Оплата консультанту * Експозиція * } \\
\text { * Ймовірність }
\end{gathered}
$$

де Оплата консультанту - коефіцієнт, що враховує розмір оплати роботи консультанта;
Експозиція - коефіцієнт, що враховує частоту звернень до консультанта протягом року;

Ймовірність - коефіцієнт, що враховує ймовірність реалізації запропонованого консультантом проекту підприємством.

Як ми зазначали вище, оплата консультанту може здійснюватись двома основними способами, але на українському ринку консалтингу, виходячи 3 досвіду дорожньо-будівельних підприємств, найчастіше використовується система ставок консультантам за відпрацьований час. Це відтворює світову тенденцію в тому, що чим більша, відоміша і довше працює консалтингова фрірма на ринку, тим частіше вона використовується погодинна оплата, чим менш відома фрірма - тим частіше вона працює за фрормою оплати своїх послуг «за успіх». Ставки для ринку України станом на кінець 2020 року наведено у таблиці 1.

Таким чином, безрозмірне значення оплати за роботу консультанту дозволяє врахувати витрати підприємства безпосередньо на роботу зовнішнього консультанта. Але витрати залежать не лише від погодинної ставки, але й від частоти звернень до консультанта протягом року, тобто внеску консультанта не лише у розробку, але й у реалізацію консалтингового проекту. Варіанти такого залучення консультанта та значення експозиції наведені у таблиці 2.

Як бачимо, цей показник дозволяє врахувати не лише частоту взаємодії 3 консультантом, але й вказує на те, що підприємствозамовник в процесі консалтингової взаємодії може припинити ії, але це не означає, що воно не скористається рекомендаціями консультанта, і не впроваджуватиме їх. Тому цей параметр перевищує одиницю, адже при множенні він дозволить врахувати у результуючому показнику витрат витрати підприємства не лише на консультанта, але й на впро-

Диференціація ставок консультантів та відповідні рівні оплати консультантам

Таблиця 1

\begin{tabular}{|c|c|l|}
\hline $\begin{array}{c}\text { 3начення } \\
\text { рівня оплати } \\
\text { консультанту }\end{array}$ & $\begin{array}{c}\text { Розмір погодинної ставки } \\
\text { оплати консультанту, } \\
\text { доларів СшА }\end{array}$ & \multicolumn{1}{|c|}{ Характеристика консультанта } \\
\hline $\mathbf{1 , 5}$ & $10000 \$ /$ год. & $\begin{array}{l}\text { керуючий партнер великої } \\
\text { транснаціональної компанії }\end{array}$ \\
\hline $\mathbf{1}$ & $500 \$ /$ год. & $\begin{array}{l}\text { стратегічний консультант великої } \\
\text { консалтингової компанії }\end{array}$ \\
\hline $\mathbf{0 , 7}$ & $250 \$$ / год. & $\begin{array}{l}\text { операційний консультант середньої } \\
\text { консалтингової компанії }\end{array}$ \\
\hline $\mathbf{0 , 5}$ & $50 \$ /$ год. & $\begin{array}{l}\text { індивідуальний консультант / консультант } \\
\text { малої фірми }\end{array}$ \\
\hline $\mathbf{0 , 1}$ & $20 \$ /$ год. & асистент консультанта (стажер) \\
\hline
\end{tabular}


Таблиця 2

Рівні експозиції залучення консультантів під час консалтингового проекту

\begin{tabular}{|c|l|l|}
\hline $\begin{array}{c}\text { 3начення } \\
\text { рівня } \\
\text { експозиції }\end{array}$ & \multicolumn{1}{|c|}{$\begin{array}{c}\text { Частота консалтингової } \\
\text { взаємодії }\end{array}$} & \multicolumn{1}{|c|}{$\begin{array}{c}\text { Характеристика реалізації } \\
\text { консалтингового проекту } \\
\text { на основі рис. }\end{array}$} \\
\hline $\mathbf{1 , 5}$ & $\begin{array}{l}\text { Постійна взаємодія } \\
\text { 3 консультантами }\end{array}$ & $\begin{array}{l}\text { Повна реалізація всіх запропонованих } \\
\text { заходів (із можливим розширенням його) та } \\
\text { впровадження рекомендацій по проекту із } \\
\text { супроводом консультантом на всіх етапах } \\
\text { реалізації проекту }\end{array}$ \\
\hline $\mathbf{1 , 3}$ & $\begin{array}{l}\text { Регулярна взаємодія } \\
\text { 3 консультантами }\end{array}$ & $\begin{array}{l}\text { Часткова реалізація запропонованих заходів } \\
\text { та впровадження рекомендацій по проекту за } \\
\text { участю консультантів }\end{array}$ \\
\hline $\mathbf{1 , 1 5}$ & $\begin{array}{l}\text { Періодична взаємодія } \\
\text { з консультантами }\end{array}$ & $\begin{array}{l}\text { Прийнято до уваги запропоновані заходи та } \\
\text { рекомендації по проекту, але можлива відмова } \\
\text { від послуг консультанта на різних етапах, що } \\
\text { супроводжується конорліктами, штрафрами, } \\
\text { судовими позовами }\end{array}$ \\
\hline $\mathbf{1 , 0 3}$ & $\begin{array}{l}\text { Мінімальна взаємодія } \\
\text { з консультантами }\end{array}$ & $\begin{array}{l}\text { Часткова реалізація запропонованих заходів } \\
\text { та впровадження рекомендацій по проекту без } \\
\text { участі консультантів }\end{array}$ \\
\hline $\mathbf{0 , 8}$ & Одноразова консультація & $\begin{array}{l}\text { Не реалізовані запропоновані заходи та не } \\
\text { погоджуються на впровадження рекомендацій } \\
\text { по проекту (можливий авансовий платіж) }\end{array}$ \\
\hline
\end{tabular}

вадження рекомендацій проекту повністю чи частково.

Третьою складовою для розрахунку витрат $€$ значення ймовірності того, що консалтинговий проект буде реалізовано. Для розрахунку цих значень було обрано 4 рівні: низький, середній, високий чи дуже високий. Але таке визначення цих категорій суб'єктивне, тому ми додали опис кожної категорії, адже особи, що приймають рішення, не розраховують ймовірність математично, а оперують інтуїтивними чи описовими фрормами характеристик. Так всі учасники процесу мають однакове розуміння цих категорій, наведених в таблиці 3.

Таким чином, якщо внаслідок діагностування проблем підприємство вирішить, що потребує зовнішнього консультування, для оцінки параметра витрат на це воно має три шкали для відбору значень розміру оплати праці консультанта, форми його участі у реалізації проекту та ймовірності того, що проект таки буде реалізовано. Значення витрат при мінімальній консалтинговій взаємодії означатиме, що буде запрошено для надання послуг стажера, для одноразової консультації і 3 десятивідсотковою ймовірністю буде реалізовано консалтинговий проект без його участі, i становитиме 0,056.

Аналогічно при участі найдорожчого консультанта протягом розробки і реалізації консалтингового проекту 3 імовірністю більше $50 \%$ визначить параметр витрат на рівні 2,475 . У цих розрахунках враховується розмір оплати роботи консультанта, і параметр

Рівні ймовірності сприйняття рекомендацій консультанта

Таблиця 3 та реалізації консалтингового проекту

\begin{tabular}{|c|c|c|}
\hline $\begin{array}{l}\text { Значення рівня } \\
\text { ймовірності }\end{array}$ & $\begin{array}{c}\text { Величина ймовірності реалізації } \\
\text { консалтингового проекту }\end{array}$ & $\begin{array}{l}\text { Характеристика варіанту } \\
\text { ймовірності реалізації } \\
\text { консалтингового проекту }\end{array}$ \\
\hline 1,1 & $>50 \%$ & $\begin{array}{c}\text { Дуже ймовірно, що проект буде } \\
\text { реалізовано }\end{array}$ \\
\hline 1 & $\begin{array}{l}132 \\
50 \%\end{array}$ & Цілком можливо \\
\hline 0,85 & $\begin{array}{l}135 \\
20 \%\end{array}$ & Можливо \\
\hline 0,7 & $\begin{array}{c}1310 \\
10 \%\end{array}$ & Малоймовірно, але можливо \\
\hline
\end{tabular}


витрат зростає, якщо реалізується проект (тобто підприємство має витрати на заходи, рекомендовані консультантом), що і враховує експозиція.

Висновки. Розглянуто один 3 показників оцінки ефективності консалтингових проектів, який традиційно розраховують як співвідношення результатів проекту до витрат. Обґрунтовано, що при консалтинговій взаємодії замовники потребують визначення цього показника, але виражають результати не у грошових одиницях, а інтегральними показниками. Відповідно методику розра- хунку витрат на основі модифрікованого підходу risk score як комплексного показника на основі добутку трьох рівнів: оплати консультанту, експозиції та ймовірності. Це доцільно саме для підприємств-замовників зовнішнього консультування, адже витрати для них значно відрізняються від витрат на той самий проект консалтингової фрірми. Такий комплексний показник витрат дозволяє врахувати різницю в оплатах послуг консультантів, частоту консалтингової взаємодії та ймовірність того, що проект буде прийнято до впровадження замовником повністю або частково.

\section{СПИСОК ВИКОРИСТАНИХ ДЖЕРЕЛ:}

1. Юксвяров Р.К., Хабакук М.Я., Лейман А.Я. Управленческое консультирование: теория и практика. Москва : Экономика, 1988. 240 с.

2. Бортнікова М.Г. Діагностування консалтингових проектів для машинобудівних підприємств : дис. канд. екон. наук : 08.00.04. Львів, 2018.

3. Как устанавливаются цены на консалтинговые услуги. URL https://www.cfin.ru/consulting/consult_price.shtml Оновлено: 24.01.2018 (дата звернення: 03.07.2020).

4. Хайт М. Вознаграждение консультанта: твёрдая ставка или гонорар от успеха. URL: https://www.cfin.ru/ management/people/motivation/consult_payment.shtml

5. Верба В.А. Концептуальні положення оцінювання управлінського консультування. Ефективна економіка. 2012. № 1. URL: http://www.economy.nayka.com.ua/?op=1\&z=886

6. Гранатуров В.М., Литовченко І.В., Харічков С.К. Аналіз підприємницьких ризиків: проблеми визначення, класифрікації та кількісної оцінки : монографія / за наук. ред. В.М. Гранатурова. Одеса : Інститут проблем ринку та економіко-екологічних досліджень НАН України, 2003. 164 с.

7. Гогіташвілі Г.Г., Карчевські Є.-Т., Лапін В.М. Управління охороною праці та ризиком за міжнародними стандартами. Київ : Знання, 2007. 367 с.

8. Calculating Risk Scores. URL: http://intaver.com/risk-scores/

\section{REFERENCES:}

1. Yuskviarov R.K., Habakuk M.Y., Leyman A.Y. (1988) Upravlencheskoe konsultirovanie: teoriya i praktika. [Management consulting: theory and practice]. Moscow: Economica. (in Russian)

2. Bortnikova M.G. (2018) Diahnostuvannya konsaltynhovykh proektiv dlya mashynobudivnykh pidpryyemstv. [Diagnosing consulting projects for machine-building enterprises] Candidate's thesis. Kyiv. (in Ukrainian)

3. Kak ustanavlivayutsya tseny na konsaltingovyye uslugi [How the prices for consulting services are set] Retrieved from: https://www.cfin.ru/consulting/consult_price.shtml (in Russian)

4. Hait M. (2005) Voznagrazhdeniye konsul'tanta: tvordaya stavka ili gonorar ot uspekha [Consultant remuneration: flat rate or success fee]. Retrieved from: https://www.cfin.ru/management/people/motivation/consult_ payment.shtml (in Russian)

5. Verba V.A. (2012) Kontseptual'ni polozhennya otsinyuvannya upravlins'koho konsul'tuvannya [Conceptual provisions for the evaluation of management consulting]. Efektyvna ekonomika, no. 1. Retrieved from: http://www.economy.nayka.com.ua/?op=1\&z=886 (in Ukrainian)

6. Granaturov V.M., Harichkov S.K., Litovchenko I.V. (2003) Analiz pidpryyemnyts'kykh ryzykiv: problemy vyznachennya, klasyfikatsiyi ta kil'kisnoyi otsinky: monohrafiya [Analysis of business risks: problems of definition, classification and quantification: a monograph]. Odessa: Instytut problem rynku ta ekonomiko-ekolohichnykh doslidzhen' NAN Ukrayiny. (in Ukrainian)

7. Hohitashvili H.H., Karchevs'ki Ye.-T., Lapin V.M. (2007) Upravlinnya okhoronoyu pratsi ta ryzykom za mizhnarodnymy standartamy [Management of labor protection and risk according to international standards]. Kyiv: Znannia. (in Ukrainian)

8. Calculating Risk Scores. Retrieved from: http://intaver.com/risk-scores/ 